\title{
Georges Gnakpa, Du féminisme dans la poésie ivoirienne
}

\section{Claudia Mansueto}

\section{(2) OpenEdition \\ 1 Journals}

\section{Edizione digitale}

URL: https://journals.openedition.org/studifrancesi/3243

DOI: $10.4000 /$ studifrancesi.3243

ISSN: 2421-5856

Editore

Rosenberg \& Sellier

\section{Edizione cartacea}

Data di pubblicazione: 1 juillet 2013

Paginazione: 496

ISSN: 0039-2944

\section{Notizia bibliografica digitale}

Claudia Mansueto, «Georges Gnakpa, Du féminisme dans la poésie ivoirienne», Studi Francesi [Online], 170 (LVII | II) | 2013, online dal 30 novembre 2015, consultato il 02 février 2023. URL: http:// journals.openedition.org/studifrancesi/3243 ; DOI: https://doi.org/10.4000/studifrancesi.3243

Questo documento è stato generato automaticamente il 2 février 2023.

\section{(c) $\odot \odot \ominus$}

Creative Commons - Attribuzione - Non commerciale - Non opere derivate 4.0 Internazionale - CC BYNC-ND 4.0

https://creativecommons.org/licenses/by-nc-nd/4.0/ 


\title{
Georges Gnakpa, Du féminisme dans la poésie ivoirienne
}

\author{
Claudia Mansueto
}

\section{NOTIZIA}

GEORGES GNAKPA, Du féminisme dans la poésie ivoirienne, Paris, L'Harmattan, 2010, pp. 120.

1 Specialista di studi francofoni, Georges Gnapkpa dedica questo suo primo saggio alla poesia femminile della Costa d'Avorio. L'autore che si sofferma sulle produzioni letterarie di Véronique Tadjo, Tanella Boni et Joachim Bohui Dali, contribuisce alla diffusione di testi poetici originali, sicuramente in contrasto con un certo canone culturale africano che tende all'annientamento della divergenza e della critica costruttiva.

2 Autrice meticcia, Véronique Tadjo irrompe sulla scena letteraria africana ed internazionale con la raccolta poetica Latérite (1984): sostenitrice del «féminisme matérialiste» (p. 55), Tadjo esorta le donne africane all'azione, all'engagement politico ed intellettuale. Originariamente combattivo e sovversivo, il continente africano deve, dunque, riscoprire quell'entusiasmo che, come ricorda Gnakpa, «est au milieu de nous, en nous et ne demande qu'à être catalysé» (p. 77). Concorde con l'orientamento interventista di Tadjo e di Bohui Dali, Tanella Boni, nelle sue numerose raccolte poetiche, non si rassegna alla sottomissione femminile: mente pensante e non oggetto, la donna africana deve ribellarsi al «suivisme et au tutorat prévu par la tradition» (p. 90) perché, solo sfuggendo all'alienazione e alla mortificazione, potrà «prendre les arènes du monde pour une humanité plus humaine» (p. 103).

3 Studio ricco di spunti riflessivi, Du féminisme dans la poésie ivoirienne consente al lettore di avvicinarsi ad un universo letterario, quello della Costa d'Avorio, sicuramente ancora poco conosciuto dal grande pubblico e spesso anche dagli studiosi. Mai banale, lo studio di Gnapka è intimamente pervaso da un velato ottimismo: la letteratura può e deve 
essere il volano indispensabile per raggiungere quegli ambiziosi traguardi esistenziali e culturali che agevoleranno la vita delle donne africane di domani. 